the lip of many hanging valleys is so little trenched is strongly suggestive of the relative inefficiency of sub-glacial torrents; for precisely in such positions of sharply increased descent should the torrents have been most effective.

W. M. D.

\section{HANGING VALLEYS IN ENGLISH LAKELAND}

AMONG the recent essays which explain hanging lateral valleys otherwise than by glacial overdeepening of the main valley is one by J. E. Marr, of Cambridge, England, on 'The Influence of the Geological Structure of English Lakeland upon its Present Features' (presidential address, Quart. Journ. Geol. Soc., London, LXII., 1906, lxvi-cxxviii ; seo p. cvii-). The greater depth of the open main valleys is here ascribed to normal erosion on weak structural features called 'shatter belts'; but under this explanationglacial erosion being disregarded-it is difficult to understand why the lateral streams, which often mouth from 500 to 1,000 feet over an open main valley floor, have accomplished so little trenching of their hanging valleys during the long period in which the main valleys were well widened by the slow processes of general subaerial erosion. There are many cases in non-glaciated districts where wide longitudinal valleys on belts of weak rocks are joined by narrow lateral valleys whose small streams enter the main valley through belts of hard rocks; the Allegheny Mountains present hundreds of examples of this kind: but in practically all such cases, even when the contrast in resistance of the hard and weak rocks is strongly pronounced, the small lateral stream has been able to cut its narrow notch in the hard rocks down to accordant grade with the main valley floor that has been opened on the weaker rocks; for the widening of the main valley by general subaerial erosion has been a relatively long process even in its weak rocks. The streams in the hanging valleys of English Lakeland would then be exceptions to this rule, if their hanging position is not to be explained by the glacial overdeepening of the main valleys. A number of cases of stream capture and rearrangement are described by
Marr in this connection; but as glacial erosion is entirely omitted from the problem, the explanation by normal stream action alone must remain in the same measure of doubt as that which now obscures the explanation of the rearrangement of various branches of the Rhine in the neighborhood of Chur, Switzerland, by normal stream action, as stated a score of years ago by Heim. W. M. D.

\section{HANGING VALLEYS IN GENERAL}

Since the convincing report on the glaciers of Alaska by Gilbert (Harriman Alaska Expedition, III., 1904), additional accounts of main-valley troughs and hanging lateral valleys, regarded as the result of glacial erosion, are given for the mountains of Alaska by $\mathbf{R}$. S. Tarr ('Glacial Erosion in Alaska' Pop. Sci. Monthly, LXX., 1907, 99-119), and by R. S. Tarr and L. Martin ("Glaciers and Glaciation of Yakutat Bay, Alaska,' Bull. Amer. Geogr. Soc., XXXVIII., 1906, 145-167; see p. 159, figs. 17 and 18); for Norway by A. P. Brigham ('The Fiords of Norway' ibid., XXXVIII., $1906^{1}$ ); for the Tian Shan mountains by Friederichsen (see these 'Notes,' March 8, 1907); for the New Zealand Alps by E. C. Andrews ('Some interesting facts concerning the glaciation of southwestern New Zealand,' Trans. Austral. Assoc. Adv. Sci., 1905, 189-205; good plates); for the Sierra Nevada by A. C. Lawson ("The Geomorphogeny of the Upper Kern Basin,' Bull. Dept. Geol., Univ. Calif., III., 1904, 291-376; see p. 329); and for the Sawatch range of the Colorado Rocky Mountains by L. G. Westgate ('The Twin Lakes Glaciated Area', Journ. Geol., XIII., 1905, 285-312) and by the undersigned ('Glaciation of the Sawatch Range, Colorado,' Bull. Mus. Comp. Zool., Harv. Coll., XLIX., 1905, 1-11).

\footnotetext{
${ }^{1}$ The pages of this article are not cited here, because the reprint from which this reference is made has been repaged, and consequently affords no sufficient indication of its original place. If editors of scientific periodicals still persist in the troublesome habit of repaging reprints, it is to be hoped that authors and reviewers will protest against it.
} 


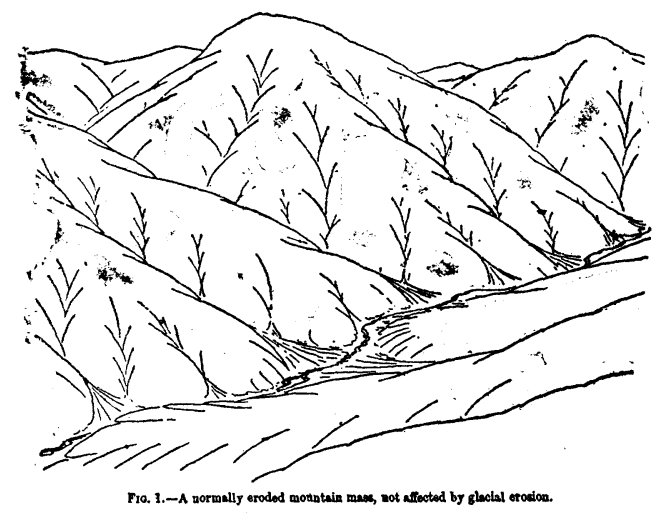

The three diagrams here presented are reproduced from an article by the undersigned on 'The sculpture of mountains by glaciers' (Scot. Geogr. Mag., XXII., 1906, 76-89), in which evidence for glacial erosion is found in a comparison of glaciated and non-glaciated mountains, entirely independent of whether glaciers are known to be capable of eroding or not. In view of the inaccessibility of the

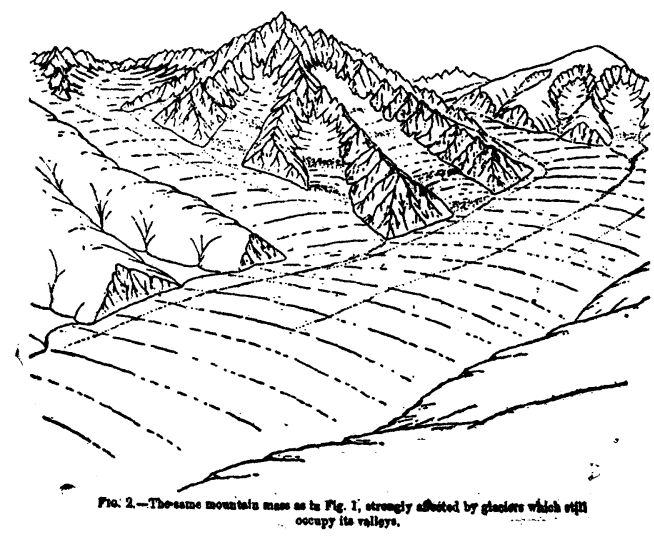

bottom of a large Alpine glacier, it is believed that the best means of determining whether it acts as a sculpturing agent or not is to be found in a comparison of districts, otherwise similar, one of which has not been glaciated, while the other has been glaciated. The diagrams are not drawn from nature, although they summarize a variety of facts seen in various mountain ranges. The third one of the series may be taken as typical of $\mathrm{La}$ Plata peak, in the Sawatch range of Colorado, and of the overdeepened trough of Lake Creek

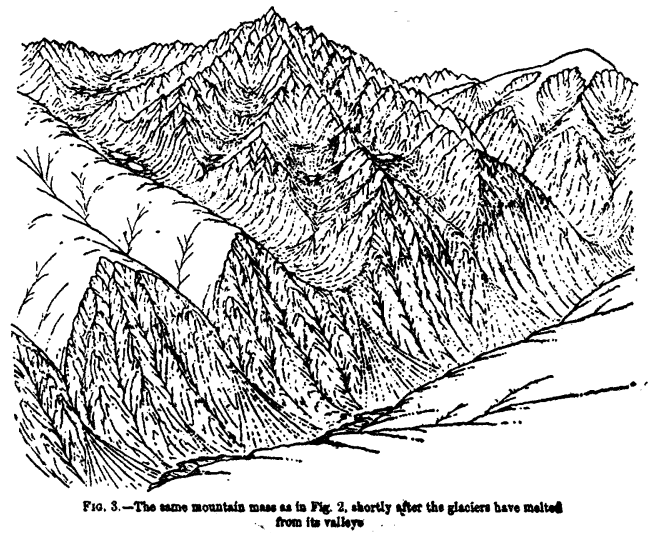

beneath it, with a well-defined hanging lateral valley between the two.

It is of interest to note in this connection that a good explanation of hanging lateral valleys was given earlier than the date, 1898, usually assigned for this important advance in rational physiography; namely, in 1888 , by La Noé and Margerie, in 'Les formes $d u$ terrain' (Paris, Service géograph. de l'armée, p. 177), where the cause of the discordance of hanging lateral valleys over their trough-like main valleys is very clearly set forth.

W. M. D.

\section{THE WISTAR INSTITUTE OF ANATOMY}

The annual meeting of the advisory board of anatomists of the Wistar Institute was held on April 14 to 16 . The members of the board present were Professors Barker, Donaldson, Gage, Huber, Huntington, Mall, McMurrich, Minot and Piersol; of the institute's staff, Drs. Greenman, Hatai, Stotsenburg and Streeter; of the institute's board of managers, Drs. Brown and Lewis.

The board held two sessions on Monday, April 15.

The general work of the year and the financial condition of the institute were explained by M. J. Greenman, the director.

The research in neurology was reviewed by Professor Henry H. Donaldson, chief of the neurological research of the institute. Professor Donaldson also reported upon the Vienna meeting of the International Brain Commission (May, 1906) and stated that an 